\title{
DEVELOPMENT OF TRANSACTIONAL COMMUNICATION MODEL FOR MIDWIFE AND POSTPARTUM MOTHER ON EXCLUSIVE BREASTFEEDING
}

\author{
Rekawati Susilaningrum, Sri Utami, Susilorini \\ School of Midwifery Soetomo Health Polytechnic Ministry of Health Surabaya \\ Prodi Midwifery Soetomo Surabaya Surabaya Polytechnic Ministry of Health \\ Email: srekawati@yahoo.com
}

\begin{abstract}
Introduction. Exclusive breastfeeding has become a major issue in Surabaya because the number of exclusive breastfeeding coverage are less than $80 \%$ which is below the national target. The purpose of this study was to develop a transactional communication model based on management between midwife and postpartum mother on exclusive breastfeeding. Method. The design used in this study was cross-sectional with 175 postpartum mothers in public health center Surabaya as the samples that recruited by purposive sampling. Questionnaires were used as instrument and data were analyzed by using descriptive statistical test and Partial Least Square (PLS). Result. The result showed that predisposing factors and enabling factors were able to improve the practice of exclusive breastfeeding directly or indirectly by transactional communication with t-table (>1.96). However, reinforcing factors could not directly improve the practice of exclusive breastfeeding. This study indicates that practice of exclusive breastfeeding could be improved with transactional communication based on human interaction theory. Discussion and conclusion. The implementation of transactional communication between midwife and mother would be able to optimize the predisposing factors, enabling factors, and reinforcing factors on the practice of exclusive breastfeeding.
\end{abstract}

Keywords: transactional communication, practice of exclusive breast feeding.

\section{INTRODUCTION}

The Indonesian health law number 36 , 2009 in article 128 explains that every baby is deserved to get exclusive breastfeeding from birth to six months, except on medical indications. As part of the government's commitment to increase breastfeeding rates, Indonesia has set up Indonesian Government Regulation number 33 of 2012 about exclusive breastfeeding. The regulation makes it possible to create an environment in which empowers women to exclusively breastfeed for the first six months and continue breastfeeding for two years or more. But this effort has not fully implemented by health worker and society. The most reasoning used are not enough breast milk, sick baby, mother's condition and various other reasons. In the end, the best solution is infant formula milk. The regulation of rooming in at the hospital, maternity clinics, and private midwives can not be implemented properly because of the limited space. Thus the mother and the baby is treated separately and might inhibit exclusive breastfeeding.

Based on data from Riskesdas on 2013 and Ministry of Health, exclusive breastfeeding coverage could not reach the Indonesian government target by $80 \%$. Those caused by the high number of pre-lacteal feeding, working mother, and infant formula milk. Pre-lacteal feeding at the age of $0-5$ months is an indicator of exclusive breastfeeding failure. The percentage of prelacteal feeding at $0-5$ months is $44.7 \%$. While the percentage of exclusive breastfeeding based on Surabaya City Health profile in 2012 was $60.52 \%$, then increase slightly in 2013 become $62.67 \%$ and $64.33 \%$ in 2014 . For the East Java province, the percentage of exclusive breastfeeding was $64.08 \%$ in 2012 and $68.48 \%$ in 2013. Although there was an increasing number, those indicate that the exclusive breastfeeding coverage, both in Surabaya and East Java still on the below of Government's target.

Based on Afifah's research in 2007, there were 11 out of 12 subjects failed to provide exclusive breastfeeding because most of them had given pre-lacteal feeding and there was only one subject who had been success giving exclusive breastfeeding until the baby was older than four months. The predisposing factors of the failure of exclusive breastfeeding are the lack of knowledge about exclusive breastfeeding and their beliefs about pre-lacteal feeding, hence encourage low motivation to provide exclusive breastfeeding. The enabling factors are a lack of counseling 
or guidance about exclusive breastfeeding and unavailability of the rooming-in facility in clinical settings. The reinforcing factors are the lack of direction from midwife about breastfeeding and the strong influence of the mother (grandmother) for infants care in nonexclusive breastfeeding (Afifah 2007). One effort to improve the coverage of exclusive breastfeeding is their transactional communication between health worker and mother by adopting the behavior theory of Lawrence Green. The purpose of this research is to develop a model of transactional communication between midwife and patient on exclusive breastfeeding by postpartum mothers at health center in Surabaya.

\section{METHODS}

This study design was a cross-sectional (observatory). Samples were postpartum mother treated at health centers in Surabaya city. The sample size was determined by rule of the thumb formula. In this study, the number of the parameter was 37 , so the samples were 175 respondents taken by multistage random sampling technique. There was 11 health center chosen by proportional random sampling. Respondent were determined by purposive sampling. Data analysis techniques used inferential analysis techniques to test the empirical model and the hypothesis proposed by the researcher. Inferential analysis using Structural Equation Modeling (SEM) was based on variance, called Partial Least Square (PLS). The research location was at the health centers in Surabaya which provided normal childbirth service. There was 21 health centers hospitalization.

\section{RESULT}

According to table 1, good knowledge, positive attitude, intermediate education, low socio-economic and support tradition were the dominant number of predisposing factors. Among enabling factor (table 2), good worker behavior, support infrastructure, and positive attitudes revealed the highest percentage. Among reinforcing factors namely good and positive public figure and understand legislation (table 3). The highest percentage of good seci 1 and good seci 2 was found within transactional communication factor (table 4).

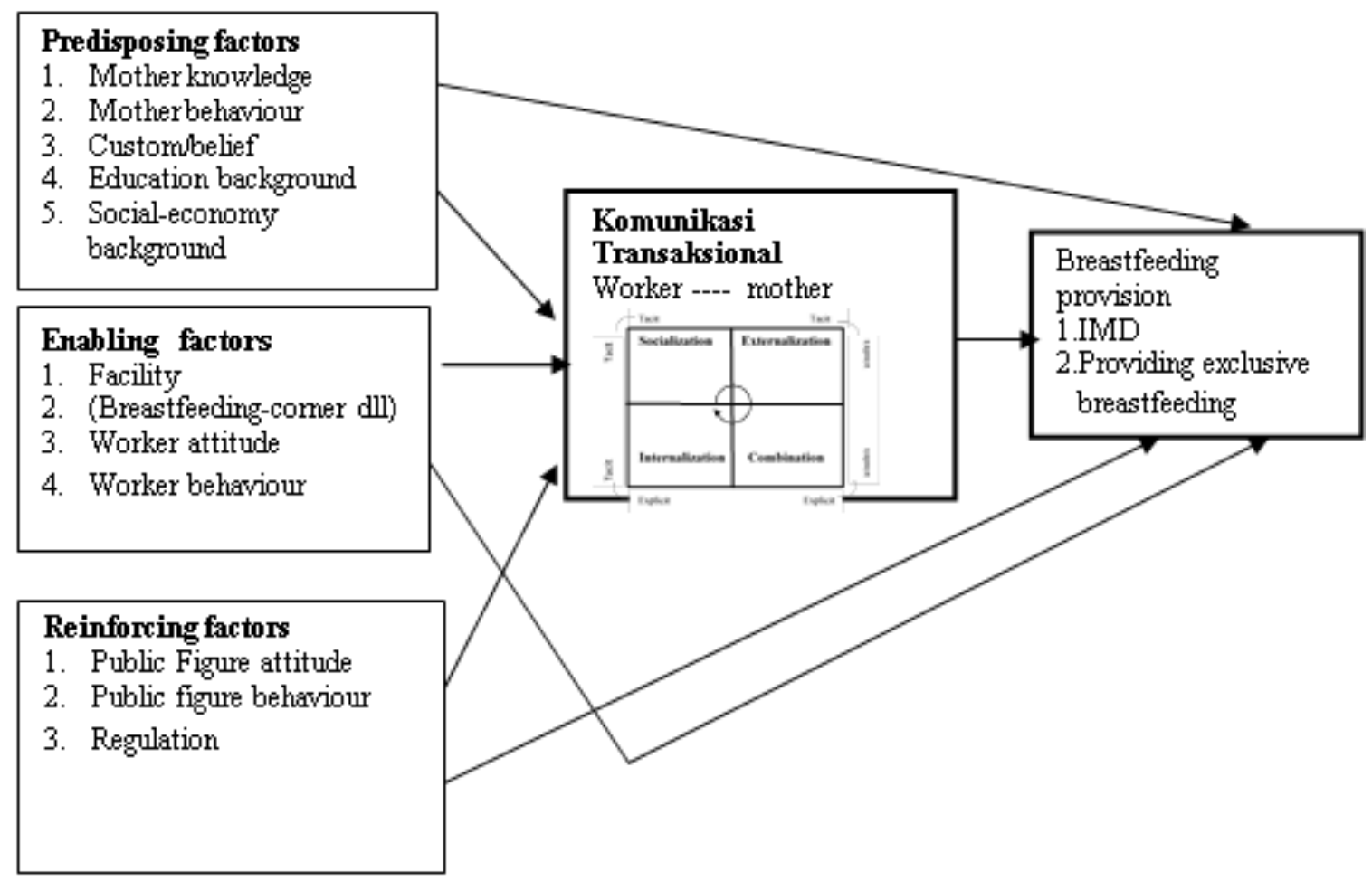

Figure 1. Model of Transactional Communication between Midwife and Patient based on Knowledge Management on Exclusive Breastfeeding Provision by Postpartum Mother 
Development of Transactional Communication Model (Rekawati Susiloningrum, et.al.)

Table 1. Distribution Respondent based on Variable of Factor predisposing

\begin{tabular}{cllcc}
\hline \multirow{2}{*}{ No. } & & PredisposingFactor & Frequency & Percentage \\
\cline { 2 - 3 } & Dimension & Category & & \\
\hline 1 & Knowledge & Low & 49 & 28.0 \\
& & Moderate & 41 & 23.4 \\
& & Good & 85 & 48.6 \\
\hline \multirow{2}{*}{2} & Attitude & Negative & 20 & 11.4 \\
& & Positive & 155 & 88.6 \\
\hline \multirow{2}{*}{3} & \multirow{2}{*}{ Education } & Basic & 66 & 37.7 \\
& & Intermediatte & 87 & 49.7 \\
& & High & 22 & 12.6 \\
\hline 4 & \multirow{2}{*}{ Socio-economic } & Low & 86 & 49.1 \\
& & Moderate & 61 & 34.9 \\
& & High & 28 & 16.0 \\
\hline 5 & Tradition & Does not support & 32 & 18.3 \\
& & Support & 143 & 81.7 \\
\hline
\end{tabular}

Table 2. Distribution of Respondent based on Enabling Factor at Puskesmas, Surabaya, 2016

\begin{tabular}{cllcc}
\hline \multirow{2}{*}{ No. } & \multicolumn{2}{c}{ Enabling Factor } & \multirow{2}{*}{ Frequency } & \multirow{2}{*}{ Percentage } \\
\cline { 2 - 3 } & \multicolumn{1}{c}{ Dimension } & Category & 23 & 13.1 \\
\hline 1 & Worker Behavior & Less & 152 & 86.9 \\
& & Good & 58 & 33.1 \\
& \multirow{2}{*}{ Infrastructure } & Does not support & 117 & 66.9 \\
\cline { 3 - 4 } & \multirow{2}{*}{ The attitude of worker } & Support & 19 & 10.9 \\
& & Negative & 156 & 89.1 \\
\hline
\end{tabular}

Table 3. Distribution of respondents based on Reinforcing Factor at Puskesmas, Surabaya, 2016 No. Reinforcing Factor

\begin{tabular}{|c|c|c|c|c|}
\hline \multirow[t]{2}{*}{ No. } & \multicolumn{2}{|c|}{ Reinforcing Factor } & \multirow{2}{*}{ Frequency } & \multirow{2}{*}{ Percentage } \\
\hline & Dimension & Category & & \\
\hline \multirow[t]{3}{*}{1.} & Public Figure behavior & Less & 78 & 44.6 \\
\hline & & Moderate & 0 & 0 \\
\hline & & Good & 97 & 55.4 \\
\hline \multirow[t]{2}{*}{2.} & Legislation & Missunderstand & 63 & 36.0 \\
\hline & & Understand & 112 & 64.0 \\
\hline \multirow[t]{2}{*}{3.} & Public Figure attitude & Negative & 33 & 18.9 \\
\hline & & Positive & 142 & 81.1 \\
\hline
\end{tabular}

Table 4. Distribution of Respondent based on Transactional Communication Factor

\begin{tabular}{|c|c|c|c|c|}
\hline \multirow[t]{2}{*}{ No. } & \multicolumn{2}{|c|}{ Transactional communications } & \multirow{2}{*}{ Frequency } & \multirow{2}{*}{ Percentage } \\
\hline & Dimension & Category & & \\
\hline \multirow[t]{3}{*}{1.} & Seci 1 & Less & 28 & 16.0 \\
\hline & & Moderate & 60 & 34.3 \\
\hline & & Good & 87 & 49.7 \\
\hline \multirow[t]{3}{*}{2.} & Seci 2 & Less & 30 & 17.1 \\
\hline & & Moderate & 58 & 33.1 \\
\hline & & Good & 87 & 49.7 \\
\hline
\end{tabular}




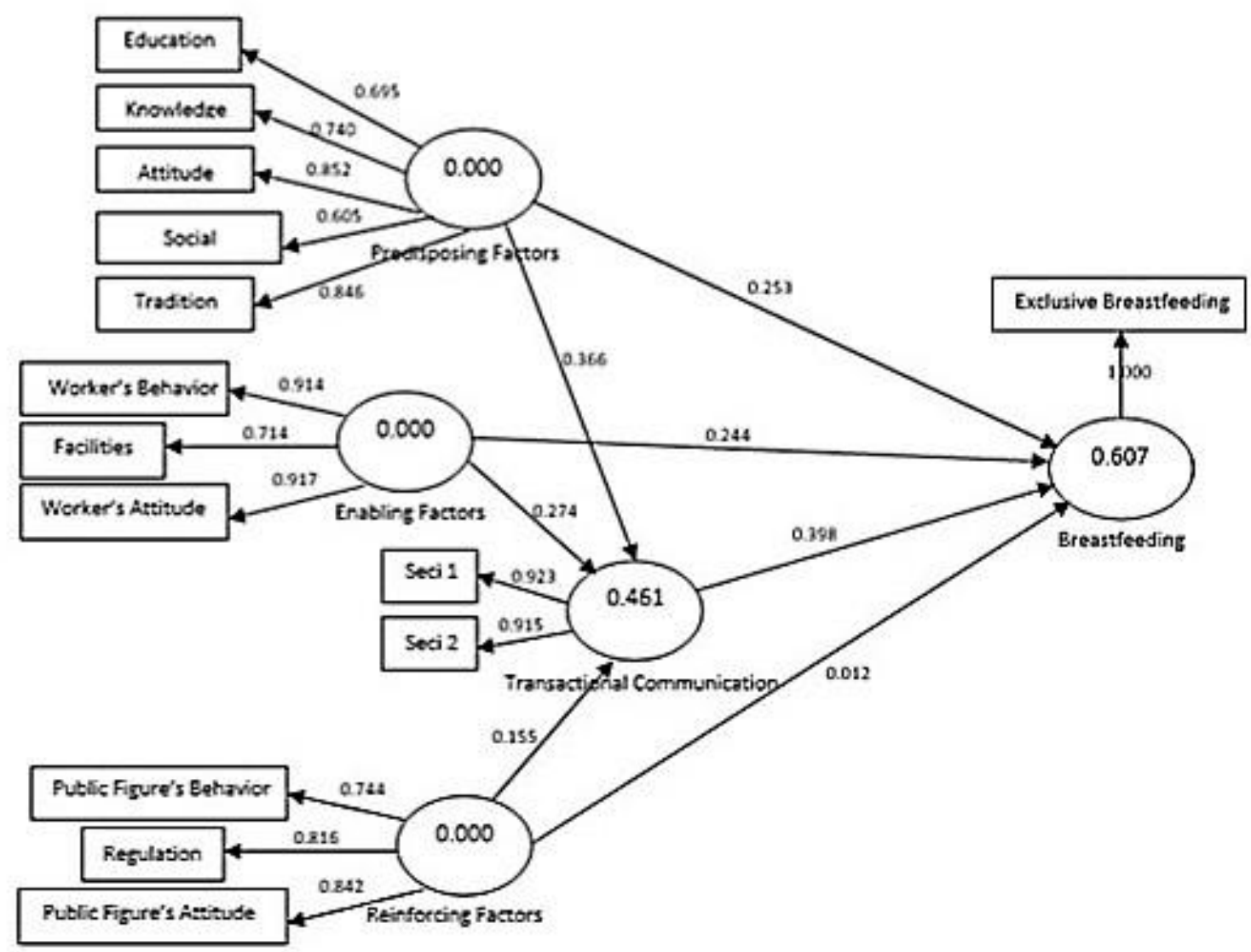

Figure 2. Result of Outer Model with Loading Factor Value using Partial Least Square (PLS)

The calculation shows predisposing factor variables, which were education, knowledge, attitude, socio-economic, and tradition, showed five dimensions had a loading factor value over 0.5 and $\mathrm{t}$ value was greater at 1.96. Among those five dimensions, which the greatest loading value was the attitude. Therefore, the attitudes, including the most influential dimension on the predisposing factor.

The enabling factor variable, which consists of worker behavior, infrastructure, and worker attitude showed three dimensions had loading factor value over 0.5 and $t$ value was greater than it at 1.96. Among those dimensions, the worker attitude was the highest at 0.9170. Therefore, the worker attitude was the most influential dimension on enabling factor.

Moreover, reinforcing factors, such as public figure attitude, public figure behavior, and legislation, showed loading factor value at 0.5 and $\mathrm{t}$ was higher than the former at 1.96. Among them attitude of public figure was the highest at 0.8417 . So, Public figure attitude was the most influential dimension on reinforcing factor.

Transactional communication variable shows that the dimensions of the first and second Seci had loading factor value over 0.5 and the greater value was $\mathrm{t}$ at 1.96. The greatest loading factor value was Seci 1 at 0.9231. Thus, the Seci 1 was the most influential dimension of transactional communication.

In breastfeeding variable, the number of dimensions was only one. So the value of loading factor for variable breastfeeding was 1. All variable constructs showed all variables had AVE value over 0.5 . So that, the entire latent variables had good validity. Results of Cross loading for education, knowledge, attitudes, socio-economic, and tradition had a greater value on predisposing factor than other variables. Thus, the dimensions of a predisposing factor were different with another dimension.

Cross loading value of worker behavioral dimension, infrastructure and worker attitude were bigger than other 
Development of Transactional Communication Model (Rekawati Susiloningrum, et.al.)

variables. So, the dimension of enabling factor was different with another dimension. Cross loading which was public figure attitude, public figure behavior, and legislation were higher than another variable. Therefore, the dimension of the reinforcing factor was different with another dimension. Cross loading value for Seci 1 and Seci 2 was greater than other variables. So, the dimension of transactional communications was different dimension with another dimension. The test results indicate that the constructs (variables) had a composite reliability value over 0.7 . So it is reliable.

\section{Inner Model Testing Stage (Structural Model Stage)}

This structural model phase aims to determine whether there is influence between variables or not. The test is carried out by using $\mathrm{t}$-test.Variable will have influence if $\mathrm{t}$ value is greater than $\mathrm{t}$ table. $\mathrm{T}$ table was at 1.96. Likewise, if the relationship among variables are negative, $t$ value is smaller than $t$ table. The calculation result can be seen in figure 3 .

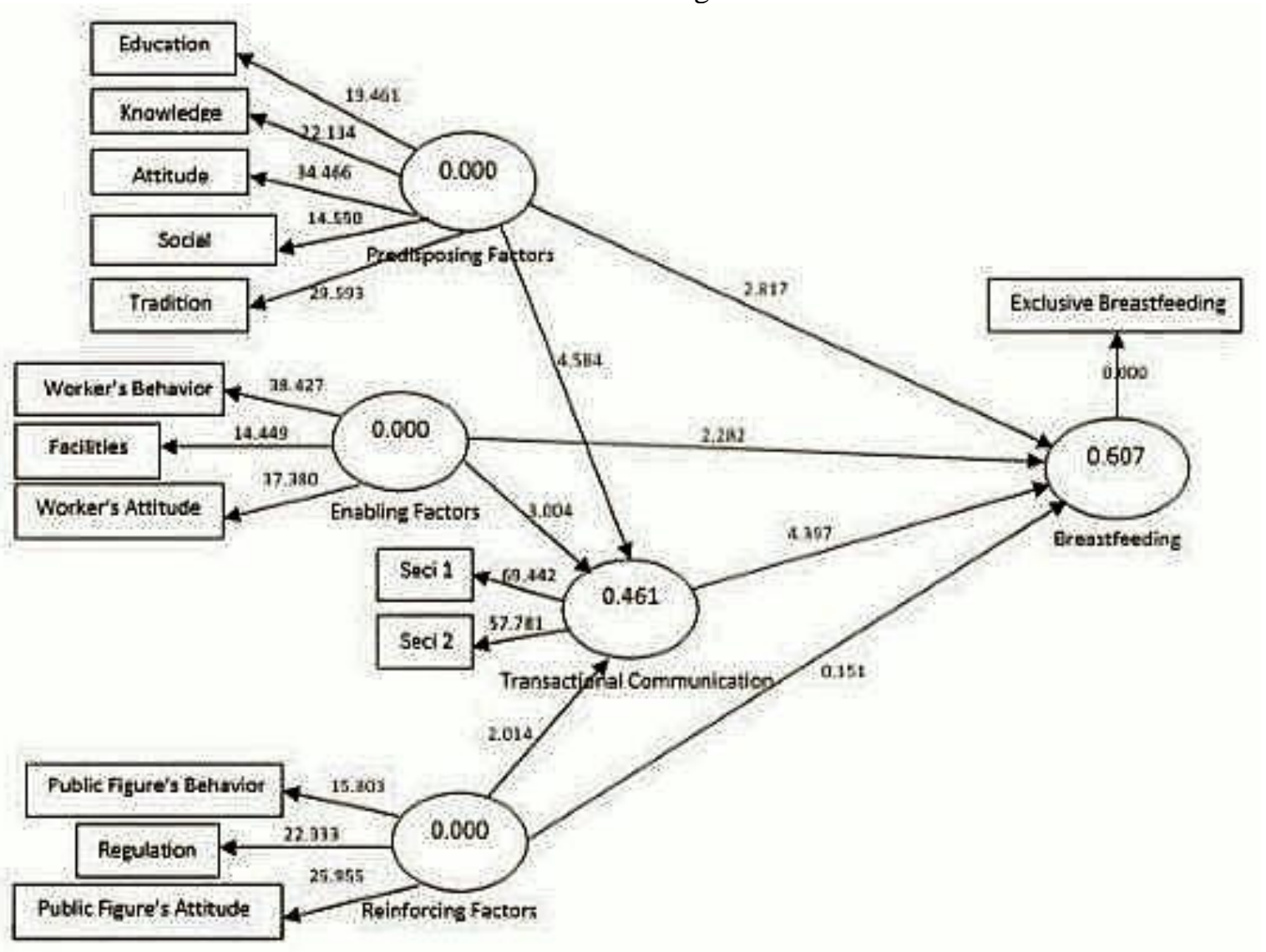

Figure 3. Result of Inner Model Test (Structural Model Stage)

Table 5. Path coefficient value and the t-Test among Variable

\begin{tabular}{lccc}
\hline \multicolumn{1}{c}{ Relationship between Variables } & $\begin{array}{c}\text { path } \\
\text { coefficients }\end{array}$ & $\begin{array}{c}\mathbf{t} \\
\text { Statistics }\end{array}$ & Information \\
\hline Predisposing factor $\rightarrow$ Communication Transactional & 0.3660 & 4.5837 & Ho rejected \\
\hline Enabling factor $\rightarrow$ Communication Transactional & 0.2740 & 3.0040 & Ho rejected \\
\hline Reinforcing factor $\rightarrow$ Communication Transactional & 0.1553 & 2.0144 & Ho rejected \\
\hline Predisposing factor $\rightarrow$ Breastfeeding & 0.2534 & 2.8172 & Ho rejected \\
\hline Enabling factor $\rightarrow$ Breastfeeding & 0.2444 & 2.2818 & Ho rejected \\
\hline Reinforcing factor $\rightarrow$ Breastfeeding & 0.0119 & 0.1505 & Ho accepted \\
\hline Transactional Communications $\rightarrow$ Breastfeeding & 0.3981 & 4.3971 & Ho rejected \\
\hline
\end{tabular}


Based on table 5, coefficient estimation of predisposing factors, reinforcing factors, and enabling factors for transactional communication had a positive value. It means the more improvement of those factors will increase the transactional communication. While the coefficient estimation of predisposing factors, reinforcing factors, and enabling factors for breastfeeding also had positive value, means that breastfeeding will be enhanced if those factors are increased. The positive value also seen on the coefficient estimate for transactional communication on breastfeeding, it means that transactional communication will lead to enhancement of breastfeeding.

T-test aimed to observe whether there was a direct influence or not. Based on t test on table 5, it showed that predisposing factors, enabling factors, and reinforcing factors had to influence to transactional communication. While the factors which had influenced to breastfeeding were predisposing factors, enabling factors, and transactional communication. Reinforcing factors did not had influence the breastfeeding behavior.

\section{Testing Goodness of Fit}

Test on the structural model was conducted with looking at the value of RSquare which is a test for the goodness-fit model. Testing of the model can be seen through $\mathrm{R}$-square value on equality among latent variables. The value $\mathrm{R}^{2}$ explains that how large exogenous (independent/free) in the model can explain the endogenous variables (dependent / dependent).

$\mathrm{R}$ square shows that predisposing factor, enabling factor, reinforcing factor influenced communication transactional which was at
0.4610 or $46.10 \%$. Meanwhile, the influence of predisposing factor, enabling factor, reinforcing factor and communication transactional on breastfeeding was at 0.6069 or $60.69 \%$.

In addition, the R-square model is also evaluated with the value of Q-square. The value of the $\mathrm{Q}$-square can be calculated with: $\mathrm{Q}^{2}=1-(1-0.4610)(1-0.6069)=0.788$. Based on the result, it can be seen that the Q-square value was at 0.788 . Because the value $\mathrm{Q} 2>0$, it can be concluded that the variables of a predisposing factor, enabling factor, reinforcing factor to the transactional communication had a good prediction of the breastfeeding.

The result of the AVE average was 0.7569 while the average of $R^{2}$ was 0.5340 so that the Goodness of Fit Index (GOF) value was 0.6358 . This value was good or great category. According to Tenenhau (2004), the value of $\mathrm{GoF}$ small $=0.1, \mathrm{GoF}$ medium $=0.25$ and $\mathrm{GoF}$ great $=0.38$.

Table 6 indicates that the indirect relationship which was greater than the direct relationship was indirect relationship reinforcing factor against breastfeeding. However, other relationships in its direct influence were greater than its indirect influence, the namely direct relationship between predisposing factor and breastfeeding, and also enabling factor and breastfeeding.

\section{Focus Group Discussion (FGD)}

FGD conducted to get feedback from the coordinator of the health center, midwife, and postpartum mother at a health center in Surabaya about the strategic issues. The results and recommendation of FGD described in table 7 .

Table 6. Indirect Relation and Its Comparison to Direct Influence

\begin{tabular}{cccc}
\hline $\begin{array}{c}\text { Indirect } \\
\text { relationships }\end{array}$ & Originally coefficient & IndirectCoefficient & $\begin{array}{c}\text { direct } \\
\text { coefficient }\end{array}$ \\
\hline $\begin{array}{c}\text { predisposing } \\
\text { factor } \rightarrow \text { breastfeeding }\end{array}$ & $\begin{array}{c}\text { predisposing factor } \rightarrow \text { Transactional } \\
\text { communications } \rightarrow \text { breastfeeding }\end{array}$ & $0.3660 \times 0.3981=0.1457$ & 0.2534 \\
\hline $\begin{array}{c}\text { enabling } \\
\text { factor } \rightarrow \text { breastfeeding }\end{array}$ & $\begin{array}{c}\text { enabling factor } \rightarrow \text { Transactional } \\
\text { communications } \rightarrow \text { breastfeeding }\end{array}$ & $0.2740 \times 0.3981=0.1091$ & 0.2444 \\
\hline $\begin{array}{c}\text { reinforcing } \\
\text { factor } \rightarrow \text { breastfeeding }\end{array}$ & $\begin{array}{c}\text { reinforcing factor } \rightarrow \text { Transactional } \\
\text { communications } \rightarrow \text { breastfeeding }\end{array}$ & $0.1553 \times 0.3981=0.0618$ & 0.0119 \\
\hline
\end{tabular}


Table 7. The result and recommendation of FGD

\begin{tabular}{lll}
\hline No & \multicolumn{1}{c}{ Theme } & \multicolumn{1}{c}{ Recommendation } \\
\hline $\begin{array}{l}\text { The lack of commitment } \\
\text { in providing exclusive } \\
\text { breastfeeding her baby }\end{array}$ & $\begin{array}{l}\text { Personal counseling on exclusive breastfeeding had to be given } \\
\text { from commencing pregnant to childbirth. }\end{array}$ \\
& $\begin{array}{l}\text { Improving maternal commitment to keep providing her breast } \\
\text { milk by emphasizing on disadvantages of no giving exclusive } \\
\text { breastfeeding and the benefits of breastfeeding, especially for } \\
\text { health and child development. }\end{array}$ \\
\hline 2. & $\begin{array}{l}\text { The lack of parent in-law } \\
\text { (grandmother of the baby) } \\
\text { support }\end{array}$ & $\begin{array}{l}\text { Socialization to grandmother about exclusive breastfeeding } \\
\text { - Involving grandmothers in implementation of exclusive } \\
\text { breastfeeding counseling } \\
\text { Class formation for grandmother that is focused on the material } \\
\text { of exclusive breastfeeding and newborn care }\end{array}$ \\
\hline
\end{tabular}

Table 8. Development of Transactional Communication Model between midwife and postpartum mother

\begin{tabular}{|c|c|c|}
\hline Structure & Standard & Development \\
\hline $\begin{array}{l}\text { Low } \\
\text { practice/ } \\
\text { behavior of } \\
\text { mother in } \\
\text { exclusive } \\
\text { breastfeeding }\end{array}$ & $\begin{array}{l}\text { 1. Breastmilk is given from } \\
\text { newborn to } 6 \text { months, and } \\
\text { it continues to breastfeed } \\
\text { until the child is } 2 \text { years } \\
\text { old. } \\
\text { 2. Personal counseling to a } \\
\text { mother with transactional } \\
\text { communication approach } \\
\text { starting from pregnancy to } \\
\text { childbirth. }\end{array}$ & $\begin{array}{l}\text { 1. Personal counseling on exclusive breastfeeding } \\
\text { with transactional communication approach. } \\
\text { 2. Increasing commitment to exclusive } \\
\text { breastfeeding mother to her baby } \\
\text { 3. Improving knowledge of grandmother about } \\
\text { exclusive breastfeeding } \\
\text { 4. Transactional communication is not only for } \\
\text { mother but also for grandmother. Grandmother } \\
\text { formation focuses on exclusive breastfeeding }\end{array}$ \\
\hline
\end{tabular}

\section{DISCUSSION}

The predisposing factor can improve transactional communication. Predisposing factor consists of education, knowledge, attitude, socioeconomic and tradition. Good knowledge, good education background, positive attitude of mother who support exclusive breastfeeding, proper learning, and positive tradition/culture that supports exclusive breastfeeding are factors that help health professional (midwife) to perform transactional communication based on knowledge management. Only a few mothers who still believe that breastfeeding will deform the breast and mothers are not allowed to eat certain food like egg, fish, chicken, and meat during breastfeeding. Those indicate only a few mothers had poor knowledge and attitude about breastfeeding.

Transactional communication can be delivered by socialization, counseling, and guidance on breastfeeding, information, and education about the benefit of breastfeeding, mother nutrition during lactation, and the negative consequences of infant formula. This communication can be done to the mother since the pregnancy until the period of exclusive breastfeeding. This is in accordance with Government Regulation No. 33 of 2012 about exclusive breastfeeding (Indonesia n.d.).

The enabling factor can improve transactional communication. Enabling factor consists of worker behavior, infrastructure, worker attitude, and communication media. In health care settings, personal communication occurs between health worker and client. In this study, interpersonal communication carried out between midwife and pregnant or postpartum. Interpersonal communication is effective communication between health worker and client. The most important media in interpersonal communication is language, both spoken and writing (Notoatmodjo 2007).

There are still some health centers not supporting to facilitate exclusive breastfeeding such as breastmilk storage because of limited 
funds. The condition is not a significant problem because the mother usually returns 24 hours postpartum. On the other hand, midwives have been providing information to mothers about the importance of exclusive breastfeeding as well as the attitude of health worker who supports exclusive breastfeeding. It needs a commitment from all health workers, especially midwives to the success of exclusive breastfeeding. It has been stated in the regulations about breastfeeding, organizers of health care facilities are required to provide information and education about exclusive breastfeeding to mother and family member since her pregnancy.

The reinforcing factors also have an influence on transactional communication. Reinforcing factor consist of public figure attitude, public figure behavior, and regulation. The reinforcing factor is an amplifier for someone to change behavior such as public figure, law, regulation, and decree. Lawrence Green, 1984 in Notoatmodjo (2007) stated that health promotion is any combination of health education and interventions related to economic, political, and organizations designed to ease behavioral and environmental changes for health.

The attitude and behavior of public figures who support exclusive breastfeeding make easier the implementation of transactional communication based on knowledge management. The public figure will be easier to affect the surrounding community. Their attitude and behavior are role model for society. This condition makes easier the midwife to socialize public about the importance of exclusive breastfeeding. Figure support will improve community empowerment in health.

A predisposing factor which consists of knowledge, attitude, socioeconomic and tradition affects on improvement the exclusive breastfeeding. According to the theory of Lawrence Green in Notoatmodjo (2007) states that a person's behavior or public about health is determined by the knowledge, attitude, belief and tradition of the person or people concerned. Knowledge is an essential aspect to determine a person's behavior to realize and decide their behavior. Knowledge is one of the predisposing factors to behavior. Mother's knowledge about breastfeeding is one of the important factors in the success of breastfeeding. Research in Bangkok, Thailand on 221 mothers using questionnaires gave good result but the behavior of providing exclusive breastfeeding was low because there were other influential factor, namely: (1) the mother was busy as career woman; (2) the influence of other people / families who care for babies; (3) the absence of exclusive breastfeeding during antenatal; and (4) the provision of infant formula after childbirth in the hospital or health facility (Li et al. 2003).

The most contributing socioeconomic variable was a mother with incomes below the minimum wage and not providing exclusive breastfeeding. Purnamawati research (2003), there is a relationship between socio-economic and breastfeeding. The result also explains the low socioeconomic will have more chance (4.6 times) to breastfeed than mothers with high socio-economic. However, Yefrida cited by (Purnamawati 2003) said there was no relationship between socioeconomic and breastfeeding practice.

Socio-economic status of the family can affect a family's ability to produce or purchase the food. A mother from a low-income family is mostly less educated and access to health information is more limited than the mother with a high-income family so that their understanding of exclusive breastfeeding is low (Suyatno 2000).

The habit has two aspects, namely knowledge and practice. In fact, the practice is influenced by knowledge. If the traditional knowledge still exists, the practice will be still running. Therefore, the socialization does not only include activities providing new knowledge to the mother. What is more important is to convince the mother that the wrong habit can harm the baby's nutritional and health status (Maas n.d.).

Enabling factor affects to breastfeeding. Enabling factor consists of worker behavior, infrastructure, and worker attitude. The important role of health workers is to protect, promote, and support breastfeeding seen by their involvement in the social aspect. As an individual who has an important role in infant nutrition and health care, health worker have a unique position to influence the organization and function of mother's health services, in before, during, and after pregnancy and childbirth. Knowledge, attitudes, and behavior 
of health workers in providing health services is crucial for breastfeeding.

Breastfeeding implementation by postpartum mother, health workers can provide a positive influence by demonstrating attitude to the mother and her family so that they see pregnancy, childbirth, and breastfeeding as an enjoyable experience gained in a friendly and supportive environment (Perinasia 1994).

Place of birth can also give effect to the provision of exclusive breastfeeding in infants because it is the starting point for mothers to choose whether to continue providing exclusive breastfeeding or give a formula given by health workers and non-health prior to her breastmilk come out.

The result of FGD has been agreed with the control of pregnant women to the health center, they will be given personal counseling on exclusive breastfeeding preparation and all aspects associated with exclusive breastfeeding. It is held with starting at trimester and continuing until after giving birth. Inadequate infrastructure such as breastfeeding corner, leaflet, and breastfeeding kit are obstacles for a counselor. It is same as a previous study showing that a breastfeeding counselor with good facilities and equipment has a tendency to have good performance when compared with a breastfeeding counselor that is not supported by complete facilities and equipment (Amirudin 2008).

There is no influence of reinforcing factor to breastfeeding. Reinforcing factor consist of public figure attitude, public figure behavior and regulation. Regulation or policy is a series of concept and principle guide to conduct a certain work. The policy is a guideline for action likely to get the desired result. A policy is a written rule that a formal decision of the organization which are binding and regulates behavior to create a new value system in society. If the policy at health center supports exclusive breastfeeding program, breastfeeding will be easier for six months during implementation. But if there is no policy, despite the knowledge and attitudes of health workers has been good to practice exclusive breastfeeding, it will still be an obstacle.

FGD concluded that health center does not provide or does not impose any infant formula with no excuse. The health center has imposed the rule that the child's birth will do the IMD and followed by exclusive breastfeeding and continued breastfeeding until the child is two years old. There is no effect of this regulation in improving exclusive breastfeeding behavior caused by a misunderstanding of client or mother. Or it could be due to the client merely know about the rules of exclusive breastfeeding. But do not understand the content of the regulation. Therefore, the rule which supports a policy should be socialized for client and society.

Transactional communication improves the mother's behavior to implement exclusive breastfeeding. Transactional communication model emphasizes sending and receiving messages that continue over time in an episode of communication. Communication is a cooperative process, in which the sender and receiver of the message, the midwife and mother/patient, have a responsibility to the impact and effectiveness of communication (Komala 2009).

Transactional communication assumes that we are continually sending and receiving messages, dealing with verbal and non-verbal elements. In other words, communicant conducts on the negotiation process about the meaning of communication. Transactional communication has been done by the midwife with mother since the pregnancy, giving birth and post-partum. Personal communication aims to improve the knowledge, attitude, and practice of mother in breastfeeding (Rohim 2007).

Breastfeeding counseling is an effective way to enhance exclusive breastfeeding (Qureshi et al. 2011). The availability of breastfeeding counselor in a facility of health services is expected to provide information about the benefit, the way to breastfeeding well, and problem-solving in breastfeeding. Mother gets completely and intensively breastfeeding counseling or get counseling at least 5 visits which are more likely to provide exclusive breastfeeding until six months (Nankunda et al. 2010).

Transactional communications model between midwife and patient is based on knowledge management. It used analysis of measurement model and structural model and then compared with the initial model. The result of the structural model is described on figure 4. Exclusive breastfeeding behavior can 
be improved by improving the quality of transactional communication. It also needs to consider predisposing factors, enabling factors and reinforcing factors. The effective transactional communication between midwife and mothers will be able to optimize the behavior of exclusive breastfeeding.

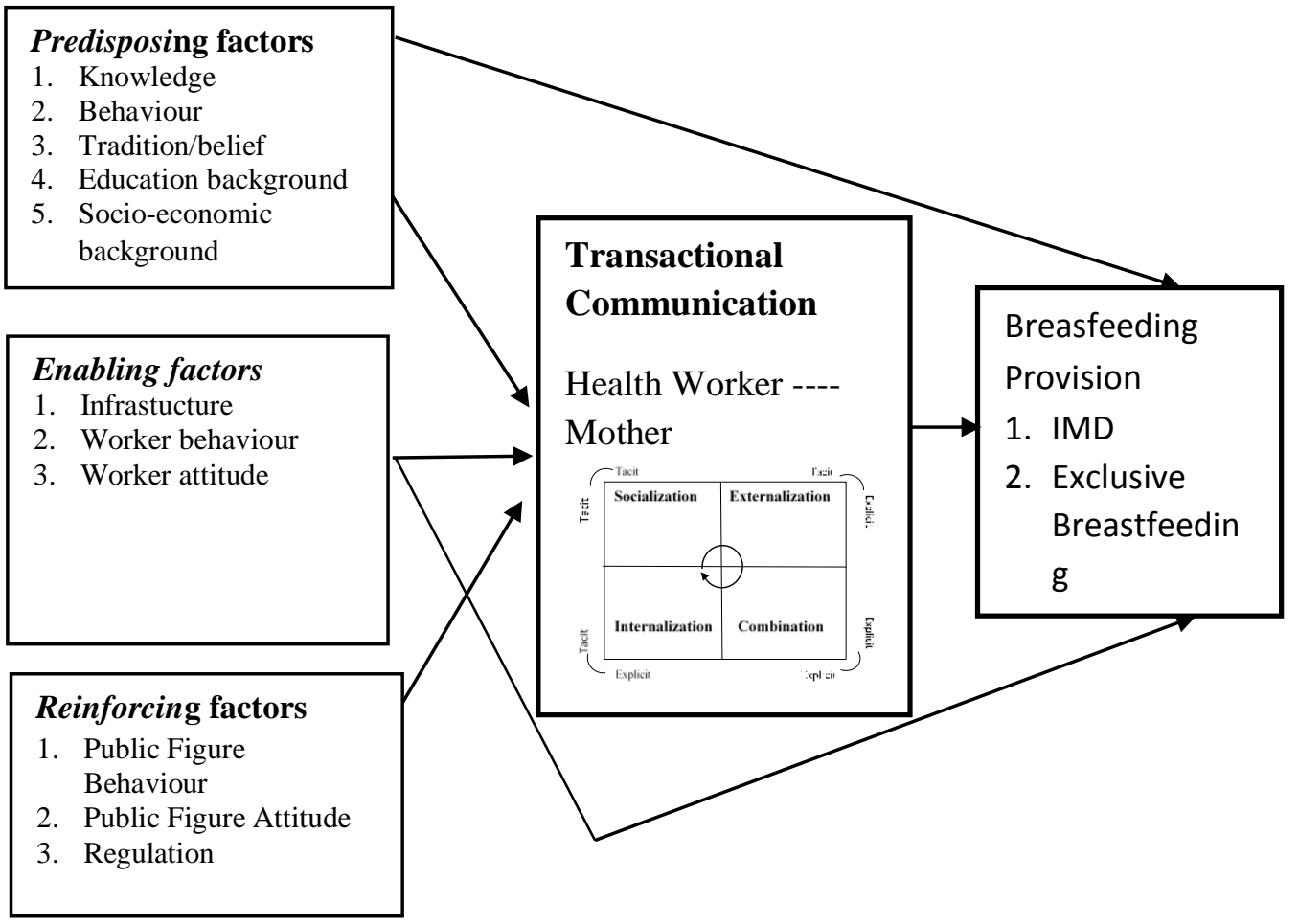

Figure 4. Research Finding of Transactional Communication Model between Midwife and Postpartum in providing exclusive breastfeeding

\section{CONCLUSION}

Predisposing factor, enabling factor, the reinforcing factor can improve the process of transactional communication and improve the behavior of mother to give exclusive breastfeeding. Transactional communication between the midwife and the client can improve the behavior of mother in exclusive breastfeeding. Reinforcing factor can improve the transactional communication between midwife and client, but can not increase directly to the mother's behavior in exclusive breastfeeding. Reinforcing factor will be able to improve the behavior of mother in exclusive breastfeeding if there has been an effective communication between the midwife and client. Transactional communication between the midwife and client has an important role to improve mother's behavior in increasing exclusive breastfeeding provision.

It needs further studies related to mother's behavior in exclusive breastfeeding by testing a model of transactional communication between midwife and client in health improvement, both of mother and baby's health. The midwife needs to improve transactional communication between midwife and client.

\section{REFERENCES}

Afifah, D.N., 2007. Faktor Yang Berperan Dalam Kegagalan Praktik Pemberian ASI Eksklusif (Studi Kualitatif di Kecamatan Tembalang, Kota Semarang. Universitas Diponegoro Semarang. Available at: http://core.ac.uk/download/pdf/11702480 .pdf.

Amirudin, 2008. Pengaruh Motivasi terhadap Kinerja Konselor ASI Eksklusif di Kabupaten Aceh Barat Propinsi Naggroe Aceh Darussalam. Universitas Sumatera Utara Medan.

Indonesia, P.R., Pemberian Air Susu Ibu Eksklusif, Indonesia. 
Komala, L., 2009. Ilmu Komunikasi: Perspektif, Proses, dan Konteks, Bandung: Widya Padjajaran.

Li, L., Zhang, M. \& Binns, C.W., 2003. Chinese mothers' knowledge and attitudes about breastfeeding in Perth, Western Australia. Breastfeeding review: professional publication of the Nursing Mothers' Association of Australia, 11(3), pp.13-9. Available at: http://www.ncbi.nlm.nih.gov/pubmed/14 768309 [Accessed May 30, 2017].

Maas, L.T., KESEHATAN IBU DAN ANAK : PERSEPSI BUDAYA DAN DAMPAK KESEHATANNYA. Available at: http://library.usu.ac.id/download/fkm/fk $\mathrm{m}$ linda2.pdf [Accessed May 30, 2017].

Nankunda, J. et al., 2010. \&quot;She would sit with me\&quot;: mothers' experiences of individual peer support for exclusive breastfeeding in Uganda. International Breastfeeding Journal, 5(1), p.16. Available at: http://www.ncbi.nlm.nih.gov/pubmed/20 977715 [Accessed May 30, 2017].

Notoatmodjo, 2007. Promosi Kesehatan dan Ilmu Perilaku, Jakarta: Rineka Cipta.

Perinasia, 1994. Melindungi, Meningkatkan, dan Mendukung Menyusui: Peran Khusus pada Pelayanan Kesehatan Ibu Hamil dan Menyusui Pernyataan., jakarta.

Purnamawati, S., 2003. FAKTOR-FAKTOR YANG BERHUBUNGAN DENGAN POLA PEMBERIAN ASI PADA BAY1 USIA EMPAT BULAN (Analisis Data Susenas 2001) | Purnamawati | Media Penelitian dan Pengembangan Kesehatan. Media Litbang Kesehatan, XIII(3), pp.29-37. Available at: http://ejournal.litbang.depkes.go.id/index .php/MPK/article/view/1055/578 [Accessed May 30, 2017].

Qureshi, A.M. et al., 2011. Using community volunteers to promote exclusive breastfeeding in Sokoto State, Nigeria. The Pan African medical journal, 10, p.8. Available at: http://www.ncbi.nlm.nih.gov/pubmed/22 187590 [Accessed May 30, 2017].

Rohim, S., 2007. Teori Komunikasi: Perspektif, Ragam dan Aplikasi, Jakarta: Rineka Cipta.

Suyatno, 2000. Pengaruh Pemberian Makanan Pendamping ASI (MP-ASI) Tradisional terhadap kejadian ISPA, Diare, dan Status Gizi Bayi pada 4 (empat) bulan Pertama Kehidupannya. Universitas Gajah Mada Yogyakarta. Available at: https://core.ac.uk/download/pdf/1171680 $0 . p d f$. 